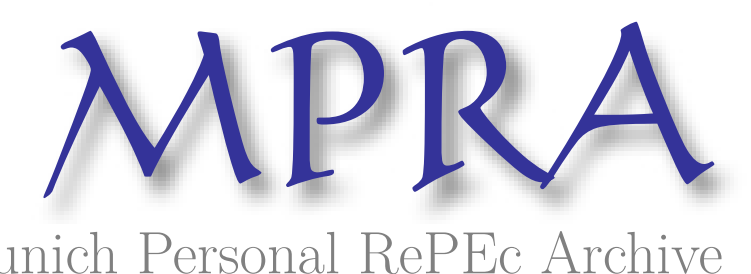

Munich Personal RePEc Archive

\title{
Institutions Matter differently depending on the Ownership Types of Firms: \\ Interacting Effects on Firm Productivity in China
}

Lee, Hyuntai and Lee, Keun

2018

Online at https://mpra.ub.uni-muenchen.de/110769/

MPRA Paper No. 110769, posted 23 Nov 2021 09:26 UTC 


\title{
Institutions Matter differently depending on the Ownership Types of Firms:
}

Interacting Effects on Firm Productivity in China

Revised: January 2018

\author{
Hyuntai Lee*
}

Keun Lee**

\begin{abstract}
*Research Fellow, Korea Institute for International Economic Policy, xiantaikor@gmail.com

** Corresponding author and Professor of Economics, Seoul National University, kenneth@snu.ac.kr
\end{abstract}

$\dagger$ Earlier versions of this paper have been presented at various occasions, including the $1^{\text {st }}$ World Congress of Comparative Economics held in Rome in Summer 2015. The authors would like to thank important comments from two referees. The second author acknowledges the financial support received from the SSK program (NRF2013S1A3A2923769) of the National Research Foundation of Korea 
Abstract

Ownership and institutions are regarded as key determinants of firm performance. Using data of Chinese firms from 1998 to 2009, this study tests the separate and interacting effects of ownership and institutions. The divergent performance of firms can be explained from the heterogeneous ownership context, as confirmed by the literature, and through variations in the way that firms of different ownership types use and exploit institutions. Privately owned firms tend to exploit considerably larger benefits from the same institutions in comparison with foreign-owned (FEs) or state-owned enterprise (SOEs). FEs or SOEs also obtain some benefits; however, these benefits are significantly smaller than those obtained by private enterprises (PEs). Results can be attributed to the differences in the aims and incentives of firms with diverse ownership types. While the initial productivity of PEs may be lower than that of FEs at the low levels of institutional development, , PEs are shown to eventually catch up with FEs because institutions develop further over time to be better exploited by PEs than Fes. Hence, any policy design should consider this coevolving nature of institutions and firm ownership; whereas private firms cannot prosper without sound institutions, institutional development may be useless unless there are private firms that can benefit from this institutional development.

Keywords: firm productivity; institutions; ownership; Chinese economy; coevolution; private firms, foreign-owned firms. 


\section{Introduction}

The roles of institutions and ownership in determining firm productivity comprise an important topic in the economic and management research of firms. The current study falls within this broad topic. In particular, this study focuses on how these roles interact with one another because this area represents a gap in the literature. Many studies have estimated the effect of institutional changes on firm productivity (Baptista and Swann, 1998; Khanna and Palepu, 1997; Chan et al., 2010; Ma et al., 2013). However, the possibility that this effect may vary depending on the types of firm ownerships has received minimal research attention. Moreover, despite the considerable number of studies on the divergent effects of ownership types on firm productivity (Coase, 1960; Demsetz, 1988; Cuervo and Villalonga, 2000; Kornai, 1980; Dollar and Wei, 2007; Bai et al., 2009; Dougherty et al., 2007; Li et al., 2012), only a few of them have explored the possibility that these divergent effects may be attributed in part to the discrepancies in the abilities of firms of different ownerships to take advantage of institutions. Therefore, the present study focuses on the interaction between ownership and institutions and attempts to contribute to the literature by identifying the determinants of firm performance.

We approach this issue using data from firms in China, where firms of diverse ownership tend to emerge and institutions are changing. Thus, this country is a unique and ideal place through which the various roles of ownership and regional institutions can be explored. First, Mainland China comprises 31 subnational regions (22 provinces, 4 municipalities, and 5 autonomous regions). Each region has its own market institution within which firms operate; meanwhile, each local government plays an important role in shaping the infrastructure, education, and innovation systems, as well as other public services in the region to stimulate regional economic development. Therefore, these regions tend to differ from one another in terms of the levels of institutional development, which exerts varying levels of influence on firms. Second, China has a unique industrial structure in which state-owned, private, and foreign-invested companies comprise a substantial portion of its economy in the $21^{\text {st }}$ century (Bai et al, 2009; Sachs and Woo, 2001).

Originating from the gradual economic reform of China (Naughton, 2007), these three types of ownership had varied effects on firm performance in China during this economic period. Moreover, they continue to coexist and compete with one another within markets.

Using a large sample of Chinese firms operating from 1998 to 2009, this study shows that the divergent performance of firms can be explained not 
only from the heterogeneous ownership context, as confirmed by the literature, but also by the differences in the way firms of different ownership types use and exploit the same institutions. Moreover, the effects of institutional development on firm productivity depend on the ownership type. Among the ownership types, private ownership enjoys the most productivity growth benefits from the development of subnational level institutions. Foreign-owned enterprises (FEs) also obtain some benefits, but these benefits are significantly smaller than those gained by private enterprises (PEs). The relationship between the productivity of state-owned enterprises (SOEs) and that of regional institutions is minimal. These results show that the influence of institutional factors on firm performance depends considerably on ownership type. Such dependence can in turn be attributed to the differences in the aims and incentives of firms of diverse ownership types.

The rest of the paper is organized as follows. Section 2 introduces existing literature on the roles of institutions and ownership in determining firm performance. The main hypotheses are also developed in this section. Section 3 describes the data and formulates the key variables. Section 4 introduces an empirical methodology and provides the results related to the hypothesis. Section 5 offers a summary and some concluding remarks.

\section{Literature and Hypotheses}

\section{Institutions and firm productivity}

Economic institutions refer to the rules and standards that comprise all business transactions of a region (Wan and Hoskisson, 2003). Subnational regions within a country may have different levels of institutions (Meyer and Nguyen, 2005; Porter, 1998). In particular, subnational regions in developing countries exhibit a high level of heterogeneity in the development of their products, capital, and intermediate markets (He, 2003). Some regions are more troubled by institutional voids than others (Khanna and Palepu, 1997; Wei et al., 1999; Ma et al., 2013). As a result, firms in less developed subnational regions face greater difficulty and uncertainty in doing business than those in developed regions because market transactions in subnational regions are not highly efficient (Ma et al., 2013). A subnational government can improve institutional conditions by developing market institutions and formulating formal rules of transactions in the region (Ma and Delios, 2010; Wan and Hoskisson, 2003). These rules can improve firm performance.

Subnational regions within a country can also be dissimilar in terms of the abundance level of various forms of capital, such as infrastructure, human, 
and knowledge capital (Cantwell, 2009; Meyer and Nguyen, 2005). The level of capital in a region is highly related to the nature of firm production (Wan and Hoskisson, 2003). Therefore, local government investments in physical infrastructure, education institutions, and innovation systems can contribute to the productivity growth of firms (Driffield et al., 2002). For example, a highly educated workforce may help foster the absorptive capacity of a firm with regard to the generation of new product ideas and the acquisition of new knowledge, thereby contributing to firm productivity.

In summary, subnational regions within an economy tend to be heterogeneous in terms of institutional factors. Such heterogeneity provides firms with differential opportunities and constraints that shape the cost and return potential of their business activities and ultimately lead to performance differences. Thus, subnational institutions matter in explaining the performance variations of firms operating in China, whose subnational regions are largely heterogeneous in terms of institutional development. However, few solid empirical analyses of the effect of subnational institutions on firm performance in China exist. Some exceptions are the works of Dollar et al. (2005), Chan et al. (2010), and Ma et al. (2013). Dollar et al. (2005) investigate the relationship between investment climate and firm performance by drawing on firm-level surveys in Bangladesh, China, India, and Pakistan. They show that variations in investment climate across locations can explain much of the variation in growth rates. Systematic variation exists across cities within countries. They further show that total factor productivity is systematically related to investment climate indicators. Chan et al. (2010) investigate the extent to which subnational region effects can explain the variations in foreign subsidiary performance in two host countries, namely, the United States and China. They examine a panel data set with more than 45,000 foreign subsidiaries formed by 1,842 Japanese multinational corporations (MNCs) in 34 states in the United States and in 21 provinces in China over a 10-year period (1996 - 2005). Their results suggest that subnational region effects are statistically significant in explaining performance variations of foreign subsidiaries (Chan et al., 2010). Ma et al. (2013) also examine the extent to which subnational region effects can explain performance variation. They empirically decompose the variance of the performance of the subsidiaries of Fortune Global 500 corporations in China from 1998 to 2006. Their results show that subnational region effects are statistically significant in explaining the variation of subsidiary performance and that the interactions of such effects with the industry, corporate parent, and home - country effects are also significant and economically important (Ma et al., 2013). However, the variance component 
analysis they use fails to measure the level of influence that a specific institutional factor exerts on performance. Thus, other econometric analyses are needed to obtain the coefficients of explanatory variables through which the scope of influence on performance can be determined.

Despite their significant contributions, previous studies, including those of Dollar et al. (2005), Chan et al. (2010), and Ma et al. (2013), have several limitations. First, the concern of the majority of these studies is the degree to which subnational region effects can explain the heterogeneity of foreign subsidiary performance. However, no explanation addresses why we should limit our research to foreign firms when in fact, regional institutional factors can affect both domestic and foreign firms that conduct business in the region. Second, no study has focused on the possibility of institutional effects varying according to ownership. Institutional effects on firm productivity, even in a province of China, can differ depending on ownership because each type of ownership involves specific business goals and constraints on business activities in China. Lack of attention to such possibility may limit our understanding of the ways through which subnational institutions exert influence. We seek to address these limitations theoretically in the present study; thus, we develop and test specific hypotheses on the effects of subnational institutions on the productivity of Chinese firms.

\section{Ownership and firm productivity}

Coase (1960) emphasizes that ownership affects how economic benefits are distributed among stakeholders and how much of the earnings the owners can keep. Owners can also decide on how firms allocate resources in the process of production, which influences performance (Cuervo and Villalonga, 2000). The potential effects of the types of ownership on firm efficiency or productivity have drawn considerable attention from researchers in the fields of economics and business management. In emerging economies, PEs and FEs record higher performances than SOEs, although variations across countries have been observed (Estrin et al., 2009).

Studies on Chinese firms show that SOEs do not perform as well as the private sector firms (Wei et al., 2005; Xu et al., 2006; Dollar and Wei, 2007; Dougherty et al., 2007; Bai et al., 2009; Li et al., 2012; Lee, 2016). Dougherty et al. (2007) conduct an analysis of the firm using the database of a quarter million industrial companies. This database covers the period from 1998 to 2003. The authors report that the private sector operates more efficiently than the public sector firms and that the high productivity of the private sector improves profitability. Bai et al. (2009) investigate the effects 
of privatization on firm performance using a panel data set of Chinese SOEs. They identify that the privatization of SOEs results in high labor productivity. The positive effect of privatization is extensive. Li et al. (2012) examine the performance of SOEs on the basis of share - issue privatization and demonstrate that SOE output and operating efficiency increase after privatization. Dollar and Wei (2007) conduct a survey among a stratified random sample of 12,400 firms in 120 cities in China using firm-level accounting information from 2002 to 2004. They determine that on average, PEs have significantly higher returns of invested capital than SOEs even after a quarter century of reforms. Wei et al (2005) show that a large foreign equity of FEs leads to a high Tobin' s Q. Xu et al. (2006) report that FEs perform better than SOEs.

All these studies are consistent in their suggestion that enterprises operating in the private sector are more efficient than SOEs in China. However, few studies have focused on the divergent effects of ownership, which result in part from the differences in the abilities of ownership types to utilize regional institutions. In contrast to the existing literature, the current study deals with the interaction between ownership and institutions to understand their roles in determining firm productivity.

\section{Hypothesis}

We focus on the objective functions of firms of diverse ownerships to develop our hypothesis on the interaction between ownership and institutions. We also attempt to predict the economic behavior of these firms using related theories. Firms of different ownership types, namely, state, private, and foreign, may have different business goals and face different constraints. Such differences may result in different economic behaviors, particularly in the way institutions are exploited. Therefore, different ownership types can lead to different economic outcomes even though they face the same institutions.

First, FEs can access and therefore share technical and managerial knowledge with their parent companies located in their home or developed countries (Javorcik, 2004). According to the resource-based view of firm growth (Penrose, 1959), parent corporations in advanced economies have access to diverse resources within the firm, or they can easily acquire these resources from other firms, compared to firms in emerging economies (Mathews, 2002). Thus, FEs can bring a large portion of advanced resources from their parent companies to the production process in emerging economies. Compared with PEs, FEs have no strong desire to invest in regional resources transacted in local markets (Graham and Wada, 2001). 
Furthermore, MNCs, which are the parent companies of FEs, invest and maximize profit on a global basis. Thus, MNCs tend to be more cautious with regard to huge long-term investments in a specific region than PEs, which have roots in the area. On the one hand, MNCs can repatriate profits without expanding investment over time once they have successfully settled in their host countries (Seabra and Flach, 2005). On the other hand, MNCs tend to decrease their investment in a specific region in the long run if they lose location advantage because of rising wage rates or the lack of tax breaks (Dunning, 1998). FEs may depend less on the subnational region in terms of acquiring the resources they need. For example, FEs may not need to hire local human capital if they can bring in talented workforce from their parent companies. Therefore, regional institutional development has minimal or less effect on FE performance. The development of institutional factors in a region may also contribute to the performance improvement of FEs, although the scope may not be as broad as that of PEs.

SOEs in China have well-developed networks of resources, particularly in financing (Nee and Mathews, 1996). Networks (guanxi) provide easy access to resources, and such associations with the government sector are stronger and more extensive for SOEs than for firms of other types of ownership. Hence, SOEs do not need to compete for the acquisition and utilization of necessary resources in local markets. The resources that SOEs need for business are largely offered by the government. The business goals of SOEs are not only profits but also promotion of public interests (Ramamurti, 1987). Thus, SOEs have less incentives to optimize the use of regional resources. Finally, SOEs are saddled with the so-called social burden, which compels them to avoid the surge of unemployment in society, which consequently results in over employment (Lin, 2011). Thus, SOEs do not fire workers by their own will. This situation implies that the development of human resources in a region may not relate at all to the performance improvement of SOEs. We infer that institutional development in a region does not considerably influence SOE performance. The development of the factors of production and market institutions in a region may have minimal contribution to the improvement in the productivity of SOEs.

According to the resource-based view of firm growth (Penrose, 1959), local firms in latecomer developing economies lack diverse critical resources (competence) for business (Mathews, 2002). Thus, the main goal of firms in developing economies is to acquire these resources and to improve the availability of such resources over the course of firm operations. Therefore, profit is sought mainly to facilitate further the expansion of these resources (Lee and Temesgen, 2009). This type of backwardness is more serious for 
private firms than for SOEs and FEs, which may have access to resources as a result of their networks with the state or parent corporations in their home countries. By contrast, PEs must strive to fully exploit whatever available external resources (institutions) in a region because of the lack of support from the government or foreign parents (Xia and Walker, 2015). PEs in China may have high propensity to rely on the supply of resources from a subnational region (Nachum, 2000). Subsequently, the development of regional institutions may lead directly to the performance change of PEs. For example, the evolution of market institutions allows PEs to pay for the minimal costs associated with market transactions, which could have possible effect on the improvement of productivity over time.

In summary, although the development of regional institutional factors is beneficial to all firms in the region regardless of ownership, PEs are desperate and are likely to obtain more benefits because of their strong predilection for the need and for investing to acquire and benefit from regional resources in local markets. Thus, the effect of institutional development on a firm may vary depending on the type of firm ownership because each type involves different incentives and business goals. The subnational regions in China exhibit significant heterogeneity in institutional development (He, 2003). Hence, testing the influence of such heterogeneity on firm productivity according to ownership type is a worthwhile endeavor. On the basis of this assumption, we hypothesize the following:

$\mathrm{H}$ : Institutional development is positively related to firm productivity. Moreover, the extent of the effect is larger in PEs than in FEs, whereas that in SOEs is minimal.

\section{Methodology}

\section{Model Specifications}

This study analyzes the factors that affect labor productivity with focus on ownership type and institutions. Labor productivity can be derived from the simple production function.

$$
Y_{i, t}=A_{i, t} \times K_{i, t}^{\alpha} \times L_{i, t}^{\beta}(1)^{1}
$$

where $Y_{i, t}$ represents output (or value added) for firm $i$ at time $t . Y_{i, t}$ is a

1 We do not assume a constant returns to scale in the production function. Therefore, $\alpha$ and $\beta$ were unknown and required estimation. 
function of total factor productivity (TFP) $A_{i, t}$, capital $K_{i, t}^{\alpha}$, and labor $L_{i, t}^{\beta}$, where $\alpha$ and $\beta$ represent the contribution shares of capital and labor to $Y_{i, t}$, respectively. TFP $A_{i, t}$ is determined by all other factors that affect the output (or value added) of the firm, excluding capital and labor.

To establish an analytical model of labor productivity of firms, we divide equation (1) by labor $L_{i, t}$ and then transform the quotient into a logarithmic function to derive the following estimation model (see the appendix for details).

$$
\ln \left(Y_{i, t} / L_{i, t}\right)=\text { cons }+\alpha \ln \left(K_{i, t} / L_{i, t}\right)+(\alpha+\beta-1) \ln \left(L_{i, t}\right)+\ln \left(A_{i, t}\right)+\mu_{i}+\varepsilon_{i, t}
$$

In estimations, log labor productivity $\ln \left(Y_{i, t} / L_{i, t}\right)$ can be regressed on $\log$ capital to labor ratio $\ln \left(K_{i, t} / L_{i, t}\right)$, log labor $\ln \left(L_{i, t}\right)$, and $\log$ TFP $\ln \left(A_{i, t}\right)$. In addition, a term $\mu_{\mathrm{i}}$ that reflects the unique time-invariant characteristics of individual firms and error term $\varepsilon_{\mathbf{i}, \mathbf{t}}$ is also included in (2). For simplicity, we assume $\ln \left(A_{i, t}\right)$ is a linear combination of some variables, namely, ownership dummies, $\boldsymbol{O}_{i, t}$, institutional variables $\boldsymbol{I}_{\mathbf{i}, \mathbf{t}}$, and other control variables, $\boldsymbol{C}_{\mathbf{i}, \mathrm{t}}$, in the regression models.

$$
\begin{array}{r}
\ln \left(Y_{i, t} / L_{i, t}\right)=\text { cons }+\alpha \ln \left(K_{i, t} / L_{i, t}\right)+(\alpha+\beta-1) \ln \left(L_{i, t}\right)+\boldsymbol{\gamma}_{\mathbf{1}} \boldsymbol{C}_{i, t}+\boldsymbol{\gamma}_{\mathbf{2}} \boldsymbol{O}_{i, t}+ \\
\boldsymbol{\gamma}_{\mathbf{3}} \boldsymbol{I}_{i, t}+\mu_{i}+\varepsilon_{i, t} \text { (3) }
\end{array}
$$

The basic specification uses labor productivity as dependent variable. Different categories of ownership dummies $\boldsymbol{o}_{i, t}$ and institutional variables $\boldsymbol{I}_{i, t}$ are used as explanatory variables, with control variables being labor to capital ratio, quantity of labor, and $\boldsymbol{C}_{i, t}$. To examine the interacting effects of institutions and ownership, we can transform Equation (3) into Equation (4) below by adding the interaction term $\boldsymbol{O}_{i, t} \times \boldsymbol{I}_{i, t}$ between institutional variables and ownership dummies. We also add the interaction term between ownership variables and several control variables, such as firm characteristics, including $\boldsymbol{o}_{i, t} \times \boldsymbol{C}_{i, t}$.

$$
\begin{array}{r}
\ln \left(Y_{i, t} / L_{i, t}\right)=\text { cons }+\alpha \ln \left(K_{i, t} / L_{i, t}\right)+(\alpha+\beta-1) \ln \left(L_{i, t}\right)+\boldsymbol{\gamma}_{\mathbf{1}} \boldsymbol{C}_{i, t}+\boldsymbol{\gamma}_{\mathbf{2}} \boldsymbol{O}_{i, t}+ \\
\boldsymbol{\gamma}_{\mathbf{3}} \boldsymbol{I}_{i, t}+\boldsymbol{\gamma}_{\mathbf{4}}\left(\boldsymbol{O}_{i, t} \times \boldsymbol{I}_{i, t}\right)+\boldsymbol{\gamma}_{\mathbf{5}}\left(\boldsymbol{O}_{i, t} \times \boldsymbol{C}_{i, t}\right)+\mu_{i}+\varepsilon_{i, t}
\end{array}
$$

The coefficient vector on the interaction term between institutional variables and ownership $\boldsymbol{\gamma}_{\mathbf{4}}$ in the regressions indicates the differences in the effects of institutional variables on various ownership types. If the baseline ownership is a private one, then $\boldsymbol{\gamma}_{\mathbf{4}}$ indicates the differences in the effects 
between PEs and FEs (or SOEs). This method allow us to verify whether PEs tend to enjoy larger effects from institutions in comparison with FEs or SOEs.

If the regressors are correlated with the individual unobserved effects, $\mu_{i}$, then the fixed effect estimator is consistent, whereas the ordinary least square regression estimator is inconsistent (Baum, 2006). In our study, firmlevel heterogeneity must be controlled; thus, we focus on the fixed effect estimation, the results of which are also consistent with those of the F-test and Hausman test. We present the results of the tests for confirmation.

\section{Data and Definition of variables}

\section{Data}

This study uses the Chinese Industrial Enterprises Database of the National Bureau of Statistics (NBS) of China. The data cover the period of 1998 - 2009, and include all industrial enterprises with annual sales of 5 million yuan or higher. Compared with the variables in the datasets of other countries, the set of available variables in the Chinese dataset is highly comprehensive (Dougherty et al., 2007). ${ }^{2}$ For each firm, the dataset provides both balance sheet data and basic information, such as ownership structure, industry, location, and employment. Therefore, the dataset presents detailed insights into the development of Chinese enterprises. A demerit of the database (i.e., the small number of firms operating for a consecutive number of years) results from firm exit and entry. Considering the demerit, we use an unbalanced panel for analysis.

The original dataset covers almost 800,000 unique firms that report their principal financial and economic results annually to the government. The original dataset included 2,050,563 observations. However, firms with zero or negative age, sales, asset, liquidity, or employment were removed from the dataset. All these deletions reduced the sample size to 1,997,616 (2.6\% loss). With this exclusion, we remove the effect of outliers and use the dataset for this study properly.

\section{Labor Productivity and Ownership Type}

As the dependent variable, labor productivity is measured by sales per worker. Although value added per worker or value added per worker hour is

2 Several other studies have used earlier versions of these data to estimate various topics on firm performance in China (Dougherty et al., 2007, Chang and Wu, 2009; Brandt et al., 2012; Xia and Walker, 2015). 
commonly used to evaluate labor productivity, computing the exact value added from the NBS data is difficult because of various data problems. A description of this variable and other firm-level control variables used in this study are presented in Table 1.

\section{(Table 1 about here)}

The most important explanatory variable used in this study is the ownership variable. For different categories of ownership variables, we reclassify firms and their data items on the basis of their registered types of ownership. ${ }^{3}$ The official registration status in the data distinguishes 23 exclusive ownership types. We categorize the firms into three groups, namely, state-owned, private, and foreign firms, so that we may appraise the effect of various ownership types on firm performance. First, SOEs in this study include state-owned enterprises, state joint-ownership enterprises, state and collective joint ownership enterprises, and sole state-funded enterprises. Second, PEs include sole private enterprises, private partnership enterprises, private limited liability companies, private shareholding limited corporations, and hybrid ownership firms that are known to pursue private profits. Lastly, FEs include Hong Kong-, Macao-, and Taiwan-invested enterprises as well as other foreign-invested enterprises.

Panel $\mathrm{A}$ in Table 2 shows the number and percentage of sample firms under various types of ownership from 1998 to 2009. The share of PEs increased rapidly from $50.2 \%$ to $79.8 \%$, whereas that of SOEs decreased significantly from $33.5 \%$ to $2.6 \%$. The total share of FEs remained stable at approximately $15 \%-20 \%$ for the period. This overall trend shows the rapidly growing proportion of private ownership, the sharp drop in state ownership, and the stagnation of foreign ownership. The sample in this study provides a good reflection of the reality of the Chinese economy.

Panel B in Table 2 shows the labor productivity trends of firms with different ownership types. ${ }^{4}$ The difference reveals that over this period, the FEs significantly outperformed the other types of firms on average, but the productivity gaps decreased continuously over time. The sales per worker of

\footnotetext{
3 An alternative approach is to separate firms into different groups by examining the share of each firm' s paid-up capital for the following types of ownership: state, collective, individual, legal person, and foreign. However, this method has two drawbacks. One drawback is that the legal person category includes the investment stakes of state-controlled shareholding companies to private subsidiaries (Brandt et al., 2014). The other drawback is that the NBS data do not offer the share of each firm' s paid-up capital for the types of ownerships for the last two years $(2008$ - 2009)

4 In the dataset, the number of workers in 2000 is missing. Therefore, the labor productivity in that year could not be calculated.
} 
the PEs in the sample increased from 202.1 in 1998 to 568.8 in 2009, whereas those of FEs increased from 312.7 to 630.9 during the same period. The productivity gap decreased from 115.6 to 61.2 . A robust econometric analysis must be conducted to determine the reason behind the changes in the relative performance of firms with different ownership types.

(Table 2 about here)

\section{Proxy variables to measure institutional development}

For the measurement of the development of physical, human, and knowledge capitals in a subnational region in China, we use official provincial-level data of the NBS of China. Institutional variables derived from the dataset include transportation (physical capital), high education (human capital), and invention patents (knowledge capital). First, we measure the development of physical capital through the expansion of public transportation, such as railways and highways. Our measure for each province is defined as the ratio of the total length of railway and highway to the gross area of the province. Second, this study determines the development of human capital through the number of college graduates per 10,000 population in each province. Third, the number of invention patents registered per 10,000 population in each province is used to represent the development of knowledge capital.

For the market institutional development index, we use the marketization index developed by the National Economic Research Institute (NERI) (Fan et al., 2011). The NERI index is a comprehensive catalog that captures the regional market development in the following aspects: (1) the relationship between the government and the market, (2) the development of the non-state sector in the economy, (3) the development of the product market, (4) the development of the factor markets, and (5) the development of market intermediaries and legal environment (Li et al., 2009).

Table 3 presents the institutional development in the eastern, western, and central regions, as well as those for the entire country, as the average of values for the regions. These values exhibit an increasing trend over time, which highlights the rapid development of institutions in China.

(Table 3 about here)

\section{Control variables}

The two principal control variables used are (1) capital intensity 
measured by capital-to-labor ratio and (2) quantity of labor. Two variables are derived directly from the Cobb - Douglas production function. The other firm-level control variables include age, debt ratio, and current ratio, ${ }^{5}$ which are considered to affect a firm's TFP. ${ }^{6}$ These variables are used in the literature to explain firm performance. The summary statistics of these control variables are presented in Table 1 . We measure these variables using the log transformation that matches with Equation (3) for econometric analysis.

We also adjust for industry factors because differences in this dimension can influence the relative performance of firms. In the database, the sample firms are distributed on the basis of different two-digit Standard Industrial Classification industries, which form the basis for industry dummies used in the regression analysis. Year dummies are also considered an important determinant of firm performance. Time variables can capture external shocks at certain times and the standard "convergence effect" between various ownership firms over time. Finally, province dummies are included to reflect locational characteristics that affect firm performance.

\section{Results and Discussion}

\section{Separate effects of institutions and ownership}

We first present the benchmark results without the interaction terms to indicate the size of the separate effects of institutions and ownership on firm productivity. This step is intended to show the comparison of these benchmark results with the results in existing literature. Table 4 presents the regression results of the fixed effect model which is chosen based on the Hausman test. First, we observe that the coefficient of foreign ownership is positive and significant, indicating that foreign ownership has a bigger positive effect on firm performance as compared with private ownership. The coefficient of foreign ownership with respect to log sales per worker is stable at about 0.123 across the models. This result suggests that foreign ownership causes sales per worker to increase more by $12.3 \%$ as compared with private ownership. The coefficient of state ownership is negative and significant, which suggests that state ownership is negatively related to labor productivity, as shown in Column (2) in Table 4. The coefficient of state ownership is approximately -0.082 , which suggests that state ownership

\footnotetext{
5 The debt ratio, current ratio, and capital-to-labor ratio are defined as the total debt to total assets, current asset to current liabilities, and tangible fixed assets to labor, respectively.

${ }^{6}$ For financial variables such as debt ratio and current ratio, one-year lagged values are used in the regression to prevent possible simultaneity bias.
} 
drags sales per worker down by $8.2 \%$. The results do not change when we run the regression with institutional variables in Column (4) of Table 4. The findings are consistent with those in previous literature.

Second, Column (3) in Table 4 shows that the coefficients of the three institutional factors, namely, market development, human capital development, and physical infrastructure development, are all positive and significant as expected. This result matches those in existing literature. With these coefficients, we calculate the elasticity of the degree of institutional development and labor productivity. For example, the elasticity for the number of college graduates per 10,000 is about 0.152 . That is, if the degree of human capital development increases by $10 \%$, then labor productivity increases by about $1.52 \%$. In the same way, we calculate the contributions of the other institutional variables to labor productivity.

Knowledge capital was found positive but insignificant as measured by the number of invention patents per 10,000. This interesting finding can be explained as follows. The insignificance of knowledge reflects the still low or emerging stage of economic development in China. In other words, at an early stage of development, it is likely that knowledge capital may not contribute to firm performance yet. Moreover, the intellectual property rights protection level in China was lower than that in advanced countries, thereby indicating that companies are not sufficiently rewarded for their inventions. Finally, the origin of invention patent tends to be unimportant to the enterprise as knowledge capital is more mobile than others. Given the preceding findings, we focus on the interaction between ownership and institutions in the following sections.

(Table 4 about here)

\section{Interacting effects of institution and ownership}

We now turn to the relationship between institutional effects and ownership. In the regression specifications in Table 5, we include the interaction terms of ownership dummies and institutional variables, as well as those of ownership dummies and control variables to control for alternative interactions between the institution and control variables. These regressions allow the comparison between the institutional effects on PEs and those on the other types of ownership by checking the coefficients of the interaction terms of the institutional variables and ownership dummies.

Column (2) in Table 5 presents the results. We observe that the coefficients of institutional variables are all positive and statistically 
significant. The finding suggests that institutional development has a positive effect on labor productivity of PEs. The coefficient for the number of college graduates per 10,000 is about 0.169 , thereby indicating that if the degree of human capital development increases by $10 \%$, then the labor productivity of PEs increases by about $1.69 \%$.

By contrast, the coefficients of the interaction terms are all negative, and many of them are statistically significant, thereby indicating that private ownership enjoys larger positive benefits from regional institutional development in comparison with the other types of ownership. This empirical result is consistent with the hypotheses. For example, the coefficient of the interaction terms between the foreign dummy and high education is approximately -0.103 . This value indicates that when the degree of human capital development increases by $10 \%$, the rate of increase of labor productivity of FEs is less than that of PEs by $1.03 \%$. Furthermore, we can calculate the absolute size of the effects of institutional development on SOEs and FEs by adding the coefficients of the institutional variables and those of the interaction terms using the estimated coefficients reported in Table 5, and test their statistical significance by F-test. ${ }^{7}$ The results are summarized in Table 6. In Table 6, we find three institutional factors (human capital, knowledge capital, and physical infrastructure) that are positive and significant for foreign ownership and only one factor (physical infrastructure) that is positive and significant for state ownership. The coefficients are smaller than those for PEs. Therefore, we can infer that PEs tend to derive and enjoy larger benefits from the same institutional development in comparison with FEs and SOEs.

(Table 5 about here)

(Table 6 about here)

\section{Robustness Check}

For the robustness check, we present the results from the samples of different ownership firms, namely without interaction terms, to show the size and significance of the effects of institutions on the labor productivity of various ownership firms. In other words, the firm samples of PEs, FEs, and

\footnotetext{
${ }^{7}$ To obtain the coefficients of the comparison group, we can add the coefficients of the explanatory variables and those of the interaction variables. Here, the coefficient $\gamma_{3}$ of the institutional variables and the coefficient $\gamma_{4}$ of the interaction variables in equation (4) are added. F-tests are used to test the statistical significance of the coefficients.
} 
SOEs are run separately in the regressions.

The estimated coefficients and their significance are presented in

Table 7. The coefficients of all institutions are positive and significant in the regressions with the private firm sample. It is shown that institutional development positively affects the labor productivity of PEs. In contrast, in the regressions with a sample of FEs, only two out of the four institution variables (human capital and physical infrastructure) are positive and significant, while the variable of market development is negative and significant, 8 and the variable of invention patents is not significant. In the regressions with SOEs, only one institution variable is significant.

For another robustness test, we constructed a model that uses value added per worker ${ }^{9}$ as a dependent variable, despite the substantial losses of observations. ${ }^{10}$ A description of the variable in this robustness check is presented in Table 8, and regression results are summarized in Table 9. We corroborated that three institutional factors (human capital, physical infrastructure, and market development) are positive and strongly significant for private ownership, although only one factor per ownership (physical infrastructure for state ownership and human capital for foreign ownership) is positive and weakly significant. These results support our hypothesis that PEs tend to enjoy larger benefits from the same institutions compared with SOEs and FEs. The outcomes are in line with those in the previous section.

In summary, the empirical analyses support the hypothesis that the extent of the effect from institutions is larger in PEs than in FEs and SOEs, whereas that in SOEs is minimal. Thus, we are able to demonstrate that the institutional effects are stronger on PE productivity than on the other types of ownership.

(Table 7 about here)

(Table 8 about here)

(Table 9 about here)

\footnotetext{
${ }^{8}$ Although not strongly supported statistically, the one interesting finding in Table 7 is that foreign companies were negatively affected by market development. This outcome appears to be related to the fact that labor productivity is measured as sales per worker in the model and that the market share of foreign companies in China in recent years is declining because of competition with private companies that have grown along with market development (Chang, 2013).

${ }^{9}$ Value added is calculated by using the expenditure approach (Brandt et al., 2014), thus: value added $=$ output - intermediated input + value added tax payable.

${ }^{10}$ The dataset used in the paper lacked several output and intermediate input data necessary for calculating the value added. No output data were collected in 2004, and no intermediate input data were available for 2008 - 2009. If we do not use these three-year data, then nearly $35 \%$ of the total data would be lost. 
Dynamic consequences of the interacting effects on long-term performance

Based on the estimated coefficients in the performance shown in Tables 5, 6, 7, and 9, Figure 1 illustrates the dynamic effect of the interaction of ownership and institutional development on labor productivity. The graph, which shows the different sizes of the effects on institutional development according to ownership, corresponds to Tables 5, 6, 7, and 9. The differences are shown by the different slopes of the two curves. The slope of the PEs is the steepest, thereby confirming the larger effect over time of institutional development on PEs than on FEs or SOEs. The sizes of the curve slopes correspond to the capability of firms of diverse ownership to exploit the institutions. The higher intercept term (representing the initial level of productivity) for the FEs or SOEs than for the PEs is based on the results in Table 5.

An important interpretation of Figure 1 is that the productivity of the PEs lag behind that of the FEs or SOEs when the institutions are at low levels or in their early stages of development. However, PEs gradually catch up with FEs or SOEs as institutions develop over time because the PEs have stronger capabilities to use and exploit the institutions than FEs or SOEs; hence, PEs eventually overtake FEs or SOEs. These results are consistent with those of Jin et al. (2008) and Jin and Lee (2017), which suggest the declining importance of FEs or SOEs as the engines of economic growth in China.

The aforementioned results are consistent with the reasoning that PEs tend to act quickly with regard to the changes in institutional factors in a region. They use these factors effectively and seize new business opportunities well. Private ownership has stronger capability to exploit regional institutions than other types of ownership. This capability comes from the strong incentive of private ownership to exploit regional resources for profit and growth. FEs have less need to exploit local institutions in comparison with PEs because the former can rely on their parent companies abroad when seeking a large portion of productive resources; thus, they are not deeply rooted in the local economy. In comparison, SOEs are typically under government protection and network with bureaucrats; thus, they have fewer reasons to try to exploit the institutional development in their locality.

(Figure 1 about here)

\section{Summary and Concluding Remarks}


Ownership and institutions are regarded as key determinants of firm performance. This study tests the separate and interacting effects of ownership and institutions using the data of Chinese firms operating from 1998 to 2009. The divergent performances of firms can be explained not only from the heterogeneous ownership context, as confirmed by the literature, but also through the varied ways that firms of different ownership types use and exploit the same institutions. The key finding is that the effects of institutional development on firm productivity are not the same and instead vary according to ownership type. PEs tend to exploit considerably larger benefits from the same institutions, compared with FEs or SOEs. Fes or SOEs also obtain some benefits, although these benefits are significantly smaller than those obtained by PEs. The results can be attributed to the differences in the aims and incentives of firms of diverse ownership types. With a high motivation and capability to use and exploit institutions, PEs can eventually catch up with FEs because institutions develop over time. However, the productivity of PEs may be lower than that of FEs at low levels of institutional development.

This study also suggests that the influence of institutional factors on firm performance depends considerably on the ownership type of a firm and that institutions interact considerably with ownership in determining firm productivity. These results may have some policy implications. Any onesided promotion of institutional development or private entrepreneurship (start-ups) cannot be effective in fostering economic growth because these two elements tend to evolve together. On the one hand, private firms cannot prosper without sound institutions. On the other hand, institutional development is useless unless private firms that can benefit from this development emerge. This study verifies the importance of basic market mechanisms, human capital, and physical capital (transportation) from the diverse dimensions of institutions at least during the economic development at low middle-income level stages, such as China in the 2000s. 


\section{Appendix: Derivation of the Estimation Model}

The estimation equation (2) was derived from the simple production function as described. First, we suppose a standard production function:

$$
Y_{i, t}=A_{i, t} \times K_{i, t}^{\alpha} \times L_{i, t}^{\beta},
$$

where $Y_{i, t}$ represents the output (or value added) for firm $\mathbf{i}$ at time t. $Y_{i, t}$ is a function of total factor productivity (TFP) $A_{i, t}$, capital $K_{i, t}^{\alpha}$, and labor $L_{i, t}^{\beta}$, where $\alpha$ and $\beta$ represent the contribution shares of capital and labor to $\mathrm{Y}_{\mathrm{i}, \mathrm{t}}$, respectively. We do not assume a constant return to scale in the production function. Therefore, $\alpha$ and $\beta$ are unknown and must be estimated. Subsequently, dividing the above equation by labor input, we have the following:

$$
\begin{gathered}
\frac{Y_{i, t}}{L_{i, t}}=A_{i, t} \times K_{i, t}^{\alpha} \times \frac{L_{i, t}^{\beta}}{L_{i, t}}, \\
\frac{Y_{i, t}}{L_{i, t}}=A_{i, t} \times K_{i, t}^{\alpha} \times L_{i, t}^{\beta-1}, \\
\frac{Y_{i, t}}{L_{i, t}}=A_{i, t} \times \frac{K_{i, t}^{\alpha}}{L_{i, t}^{\alpha}} \times L_{i, t}^{\alpha} \times L_{i, t}^{\beta-1}, \\
\frac{Y_{i, t}}{L_{i, t}}=A_{i, t} \times\left(\frac{K_{i, t}}{L_{i, t}}\right)^{\alpha} \times L_{i, t}^{\alpha+\beta-1} .
\end{gathered}
$$

Finally, we transform the quotient into the logarithmic function below. $\ln \left(\frac{Y_{i, t}}{L_{i, t}}\right)=$ constant $+\ln \left(A_{i, t}\right)+\alpha \ln \left(\frac{K_{i, t}}{L_{i, t}}\right)+(\alpha+\beta-1) \ln \left(L_{i, t}\right)+\mu_{i}+\varepsilon_{i, t}$. 


\section{References}

Bai C-E, Lu J, Tao Z. (2009). How does privatization work in China? Journal of Comparative Economics, 37, 453-470.

Baptista, R., and Swann, G. M. P. (1998). Do firms in clusters innovate more? Research Policy, 27(6), 525 - 540

Baum, C. F. (2006). An introduction to modern econometrics using Stata. Stata press.

Brandt, L., Van Biesebroeck, J., and Zhang, Y. (2012). Creative accounting or creative destruction? Firm-level productivity growth in Chinese manufacturing. Journal of Development Economics, 97(2), 339 - 351.

Brandt, L., Van Biesebroeck, J., and Zhang, Y. (2014). Challenges of working with the Chinese NBS firm-level data. China Economic Review, 30, 339-352. Cantwell, J. (2009). Location and the multinational enterprise. Journal of International Business Studies, 40(1), 35 - 41.

Chan, C. M., Makino, S., and Isobe, T. (2010). Does sub-national region matter? Foreign affiliate performance in the United States and China. Strategic Management Journal, 31(11), 1226 - 1243.

Coase, R. H. (1960). Problem of social cost, the. JL \& econ., 3, 1.

Chang, S. J. (2013).Multinational firms in China: Entry strategies, competition, and firm performance. OUP Oxford.

Chang S-J and Wu B. (2009). Post-liberalization industry shakeout in China, 1998 - 2006. Working paper, National University of Singapore, Singapore.

Cuervo, A. and Villalonga B. (2000). Explaining the variance in the performance effects of privatization. The Academy of Management Review, 25, 581-590.

Demsetz, Harold. (1988). The theory of the firm revisited. Journal of Law, Economics, \& Organization, 4(1), 141-161.

Dollar, D., Hallward-Driemeier, M., and Mengistae, T. (2005). Investment climate and firm performance in developing economies.Economic Development and Cultural Change, 54(1), 1-31.

Dollar, D., and Wei. S. J. (2007). Das (Wasted) Kapital: Firm Ownership and Investment Efficiency in China, National Bureau of Economic Research Working Paper 13103.

Dougherty, S., Herd, R., and He, P. (2007). Has a private sector emerged in China's industry? Evidence from a quarter of a million Chinese firms. China Economic Review, 18, 309 - 334.

Dunning, J. H. (1998). Location and the multinational enterprise: A neglected factor? Journal of International Business Studies, 29(1), 45 - 66.

Driffield, N., Munday, M., and Roberts, A. (2002). Foreign direct investment, 
transactions linkages, and the performance of the domestic sector. International Journal of the Economics of Business, 9(3), 335-351.

Estrin, S., Hanousek, J., Kočenda, E., and Svejnar, J. (2009). The effects of privatization and ownership in transition economies.Journal of Economic Literature,47(3), 699-728.

Fan, G.,Wang, X., and Zhu, H. (2011). NERI Index of Marketization of China's Provinces 2011 Report, Economics Science Press (in Chinese). Graham, E.M., Wada, E. (2001). In: Drysdale, Peter (Ed.), Foreign Direct Investment in China: Effects on Growth and Economic Performance, Achieving High Growth: Experience of Transition Economies in East Asia. Oxford University Press.

He, C. F. (2003). Location of foreign manufacturers in China: Agglomeration economies and country of origin effects. Papers in Regional Science, 82(3), 351372

Javorcik, B. S. (2004). The Composition of Foreign Direct Investment and Protection of Intellectual Property Rights: Evidence from Transition Economies. European Economic Review, 48(1), 39 - 62.

Jin, F., Lee, K. and Kim, Y. K., (2008), Changing Engines of Growth in China: From Exports, FDI and Marketization to Innovation and Exports, China and World Economy, 16, 31-49.

Jin, F., and Lee, K. (2017). Dynamics of the growth - inequality nexus in China: roles of surplus labor, openness, education, and technical change in province-panel analysis.Journal of Economic Policy Reform,20(1), 1-25. Khanna, T., and Palepu, K. (1997). Why focused strategies may be wrong for emerging markets. Harvard Business Review, 75(4), 41 - 54.

Kornai, Janos. (1980). Economics of shortage. North Holland.

Lee, K., and Temesgen, T. (2009). What makes firms grow in developing countries? An extension of the resource-based theory of firm growth and empirical analysis. International Journal of Technological Learning, Innovation and Development, 2(3), 139-172.

Lee, Hyun-Tai. (2016). Causes of the Changing Performance of Firms with Diverse Types of Ownerships in China. Seoul Journal of Economics, 29(1), 95112.

Li, K., Yue, H., and Zhao, L. (2009). Ownership, institutions, and capital structure: Evidence from China. Journal of comparative economics37(3), 471490.

Li, H., Yang, Z., Yao, X., Zhang, H., and Zhang, J. (2012). Entrepreneurship, private economy and growth: Evidence from China. China Economic Review, 23(4), 948-961.

Lin, J. Y. (2011). Demystifying the Chinese economy.Cambridge University 
Press,

Ma, X., Tong, T. W., and Fitza, M. (2013). How much does subnational region matter to foreign subsidiary performance and quest; Evidence from Fortune Global 500 Corporations' investment in China. Journal of International Business Studies, 44(1), 66-87.

Ma, X., and Delios, A. (2010). Host country headquarters and an MNE' s subsequent within-country diversifications. Journal of International Business Studies, 41(3), 517 - 525.

Mathews, J. (2002). Competitive Advantages of the Latecomer Firm: A Resource-Based Account of Industrial Catch-Up Strategies, Asia Pacific Journal of Management, 19(4), 467-488.

Meyer, K. E., and Nguyen, H. V. (2005). Foreign Investment Strategies and Sub-national Institutions in Emerging Markets: Evidence from Vietnam. Journal of management studies, 42(1), 63-93.

Nachum L. (2000). Economic geography and the location of TNCs: financial and professional service FDI to the USA. Journal of International Business Studies, 31(3), 367 - 385.

Naughton, Barry. (2007). The Chinese economy: Transitions and growth. MIT press.

Nee, V., and Matthews, R. (1996). Market transition and societal transformation in reforming state socialism. Annual Review of sociology,22(1), 401-435. Penrose, E.T. (1959). The Theory of the Growth of the Firm, Basil Blackwell. Porter, M. E. (1998). Clusters and the new economics of competition Harvard Business Review, 76(6), 77-90.

Ramamurti, R. (1987). Performance evaluation of state-owned enterprises in theory and practice.Management Science,33(7), 876-893.

Sachs, J. D., and Woo, W. T. (2001). Understanding China's economic performance. The Journal of Policy Reform, 4(1), 1-50.

Seabra, F., and Flach, L. (2005). Foreign direct investment and profit outflows: a causality analysis for the Brazilian economy.Economics Bulletin,6(1), 1-15. Wan, W. P., and Hoskisson, R. E. (2003). Home country environments, corporate diversification strategies, and firm performance. Academy of Management Journal, 46(1), 27-45.

Wei, Y., Liu, X., Parker, D., and Vaidya, K. (1999). The regional distribution of foreign direct investment in China. Regional studies, 33(9), 857-867.

Wei, Z., Xie, F., and Zhang, S. (2005). Ownership structure and firm value in China's privatized firms: 1991 - 2001.Journal of financial and quantitative analysis,40(01), 87-108.

Xia, F., and Walker, G. (2015). How much does owner type matter for firm 
performance? Manufacturing firms in China 1998 - 2007. Strategic

Management Journal, 36(4), 576-585.

Xu, D., Pan, Y., Wu, C., and Yim, B. (2006). Performance of domestic and

foreign-invested enterprises in China. Journal of World Business, 41(3), 261274. 
Table 1. Descriptive Statistics

\begin{tabular}{cccccc} 
Variable & Obs & Mean & Std. Dev. & Min & Max \\
\hline $\begin{array}{c}\text { sales per worker } \\
(1,000 \text { yuan })\end{array}$ & $1,892,094$ & 364.1771 & 833.2067 & .1789678 & 73968.45 \\
\hline $\begin{array}{c}\text { capital to labor } \\
(1,000 \text { yuan })\end{array}$ & $1,892,094$ & 112.1953 & 566.9169 & .0065454 & 53191.55 \\
employ & $1,893,884$ & 252.301 & 957.3551 & 1 & 78330 \\
age & $1,993,498$ & 11.08376 & 11.14947 & 1 & 100 \\
Debt ratio & $1,993,485$ & .5837564 & .325705 & 0 & 8.450111 \\
Current ratio & $1,949,010$ & 3.961155 & 91.23036 & .0031686 & 15242 \\
\hline
\end{tabular}

Note: All financial values were measured in Chinese Yuan (RMB) at the 1998 constant price using the PPI deflator. Sources: Authors.

Table 2. Ownership Type and Labor Productivity

Panel A: Sample firms by ownership type

\begin{tabular}{|c|c|c|c|c|c|c|c|c|c|c|c|c|}
\hline $\begin{array}{c}\text { Owner } \\
\text { ship }\end{array}$ & 1998 & 1999 & 2000 & 2001 & 2002 & 2003 & 2004 & 2005 & 2006 & 2007 & 2008 & 2009 \\
\hline \multirow{2}{*}{ State } & 35,763 & 32,580 & 25,964 & 24,154 & 21,133 & 16,248 & 17,607 & 11,626 & 11,111 & 7,207 & 6,276 & 6,445 \\
\hline & $33.5 \%$ & $30.7 \%$ & $25.6 \%$ & $19.9 \%$ & $16.4 \%$ & $12.0 \%$ & $8.9 \%$ & $6.4 \%$ & $5.1 \%$ & $3.4 \%$ & $2.7 \%$ & $2.6 \%$ \\
\hline \multirow{2}{*}{ Private } & 53,612 & 55,370 & 56,990 & 73,986 & 82,669 & 91,920 & 140,013 & 132,104 & 162,406 & 162,103 & 184,854 & 201,242 \\
\hline & $50.2 \%$ & $52.1 \%$ & $56.1 \%$ & $61.0 \%$ & $64.1 \%$ & $68.0 \%$ & $70.5 \%$ & $72.6 \%$ & $74.6 \%$ & $76.5 \%$ & $78.6 \%$ & $79.8 \%$ \\
\hline \multirow{2}{*}{ Foreign } & 17,378 & 18,346 & 18,559 & 23,183 & 25,212 & 27,011 & 40,998 & 38,209 & 44,072 & 42,710 & 44,078 & 44,477 \\
\hline & $16.3 \%$ & $17.3 \%$ & $18.3 \%$ & $19.1 \%$ & $19.5 \%$ & $20.0 \%$ & $20.6 \%$ & $21.0 \%$ & $20.3 \%$ & $20.1 \%$ & $18.7 \%$ & $17.6 \%$ \\
\hline Total & 106,753 & 106,296 & 101,513 & 121,323 & 129,014 & 135,179 & 198,618 & 181,939 & 217,589 & 212,020 & 235,208 & 252,164 \\
\hline
\end{tabular}

Panel B: Labor Productivity by Ownership Type (Sales Per Worker)

\begin{tabular}{|c|c|c|c|c|c|c|c|c|c|c|c|c|}
\hline $\begin{array}{c}\text { Owner } \\
\text { ship }\end{array}$ & 1998 & 1999 & 2000 & 2001 & 2002 & 2003 & 2004 & 2005 & 2006 & 2007 & 2008 & 2009 \\
\hline Full & 203.1 & 164.0 & $\mathrm{n} / \mathrm{a}$ & 212.6 & 247.2 & 274.2 & 318.5 & 372.3 & 432.2 & 468.2 & 473.6 & 578.5 \\
\hline State & 151.2 & 76.3 & $\mathrm{n} / \mathrm{a}$ & 117.1 & 141.3 & 144.4 & 185.2 & 223.9 & 359.4 & 425.0 & 448.1 & 517.4 \\
\hline Private & 202.1 & 176.9 & $\mathrm{n} / \mathrm{a}$ & 206.2 & 240.4 & 260.0 & 303.2 & 359.3 & 414.2 & 446.4 & 452.1 & 568.8 \\
\hline Foreign & 312.7 & 280.7 & $\mathrm{n} / \mathrm{a}$ & 332.5 & 358.1 & 400.6 & 423.5 & 462.5 & 516.5 & 558.1 & 567.6 & 630.9 \\
\hline $\begin{array}{l}\text { private- } \\
\text { state } \\
\text { (T-test) }\end{array}$ & $\begin{array}{l}50.8 \\
(0.81)\end{array}$ & $\begin{array}{c}100.6 \\
(42.44)^{* * *}\end{array}$ & $\begin{array}{l}\mathrm{n} / \mathrm{a} \\
\mathrm{n} / \mathrm{a}\end{array}$ & $\begin{array}{c}89.0 \\
(5.28)^{* * *}\end{array}$ & $\begin{array}{c}99.1 \\
(4.64)^{* * *}\end{array}$ & $\begin{array}{c}115.6 \\
(28.41)^{* * *}\end{array}$ & $\begin{array}{c}118.0 \\
(6.79)^{* * *}\end{array}$ & $\begin{array}{c}135.4 \\
(9.68)^{* * *}\end{array}$ & $\begin{array}{l}54.8 \\
(0.85)\end{array}$ & $\begin{array}{l}21.5 \\
(0.86)\end{array}$ & $\begin{array}{c}4.0 \\
(0.18)\end{array}$ & $\begin{array}{c}51.4 \\
(2.60)^{* * * *}\end{array}$ \\
\hline $\begin{array}{l}\text { private- } \\
\text { foreign } \\
\text { (T-test) }\end{array}$ & $\begin{array}{l}-110.6 \\
(-18.0)^{* * * * *}\end{array}$ & $\begin{array}{c}-103.8 \\
(-19.2)^{* * * *}\end{array}$ & $\begin{array}{l}\mathrm{n} / \mathrm{a} \\
\mathrm{n} / \mathrm{a}\end{array}$ & $\begin{array}{c}-126.3 \\
(-10.9)^{* * * *}\end{array}$ & $\begin{array}{l}-117.7 \\
(-11.9)^{* * * *}\end{array}$ & $\begin{array}{l}-140.6 \\
(-10.6)^{* * * *}\end{array}$ & $\begin{array}{l}-120.3 \\
(-6.03)^{* * * *}\end{array}$ & $\begin{array}{l}-103.3 \\
(-7.12)^{* * * *}\end{array}$ & $\begin{array}{l}-102.3 \\
(-7.67)^{\text {***** }}\end{array}$ & $\begin{array}{c}-111.7 \\
(-6.02)^{* * * *}\end{array}$ & $\begin{array}{l}-115.5 \\
(-6.45)^{* * * *}\end{array}$ & $\begin{array}{c}-62.0 \\
(-2.99)^{* * * * *}\end{array}$ \\
\hline
\end{tabular}

Notes. 1. The t-value is in parentheses. . $^{* *},{ }^{* *}$, and ${ }^{*}$ in the cells indicate $1 \%, 5 \%$, and $10 \%$ levels of significance, respectively.

Sources: Authors. 
Table 3. Institutional Development in China

\begin{tabular}{|c|c|c|c|c|c|c|c|c|c|c|c|c|}
\hline Institution & Region & 1999 & 2000 & 2001 & 2002 & 2003 & 2004 & 2005 & 2006 & 2007 & 2008 & 2009 \\
\hline \multirow{4}{*}{$\begin{array}{l}\text { Human Capital: } \\
\text { College graduate } \\
\text { /10,000 population }\end{array}$} & China & 3.82 & 4.35 & 4.75 & 6.30 & 8.79 & 11.80 & 14.68 & 17.77 & 21.45 & 25.47 & 27.04 \\
\hline & East & 4.36 & 4.94 & 5.38 & 7.14 & 9.73 & 13.06 & 16.00 & 19.01 & 22.72 & 27.18 & 29.26 \\
\hline & Central & 3.47 & 3.96 & 4.18 & 5.63 & 8.30 & 10.18 & 13.51 & 17.37 & 21.05 & 24.80 & 25.44 \\
\hline & West & 2.35 & 2.69 & 2.93 & 3.56 & 5.09 & 7.07 & 9.52 & 11.92 & 15.44 & 14.57 & 14.85 \\
\hline \multirow{4}{*}{$\begin{array}{c}\text { Knowledge Capital: } \\
\text { Invention patents registered } \\
/ 10,000 \text { population }\end{array}$} & China & 0.19 & 0.36 & 0.39 & 0.51 & 0.72 & 0.87 & 1.23 & 1.48 & 1.81 & 2.38 & 2.72 \\
\hline & East & 0.26 & 0.53 & 0.55 & 0.72 & 1.00 & 1.16 & 1.67 & 2.00 & 2.45 & 3.06 & 3.54 \\
\hline & Central & 0.09 & 0.11 & 0.12 & 0.15 & 0.20 & 0.21 & 0.28 & 0.36 & 0.44 & 0.61 & 0.71 \\
\hline & West & 0.07 & 0.09 & 0.09 & 0.12 & 0.16 & 0.17 & 0.25 & 0.31 & 0.38 & 0.47 & 0.70 \\
\hline \multirow{4}{*}{$\begin{array}{c}\text { Physical Capital: } \\
\text { (railway+highway) } \\
\text { /gross area }\end{array}$} & China & 0.38 & 0.39 & 0.48 & 0.49 & 0.51 & 0.56 & 0.57 & 0.97 & 1.00 & 1.08 & 1.10 \\
\hline & East & 0.47 & 0.48 & 0.58 & 0.59 & 0.60 & 0.65 & 0.66 & 1.09 & 1.13 & 1.17 & 1.20 \\
\hline & Central & 0.30 & 0.31 & 0.38 & 0.40 & 0.41 & 0.42 & 0.44 & 0.94 & 0.96 & 1.00 & 1.03 \\
\hline & West & 0.17 & 0.18 & 0.21 & 0.21 & 0.22 & 0.22 & 0.24 & 0.40 & 0.44 & 0.54 & 0.56 \\
\hline \multirow{4}{*}{$\begin{array}{c}\text { NERI } \\
\text { Marketization Index }\end{array}$} & China & 4.77 & 5.18 & 5.84 & 6.36 & 6.97 & 7.73 & 8.32 & 8.67 & 9.17 & 9.11 & 9.43 \\
\hline & East & 5.43 & 5.95 & 6.86 & 7.42 & 7.99 & 8.62 & 9.21 & 9.57 & 10.13 & 9.90 & 10.34 \\
\hline & Central & 3.91 & 4.04 & 4.06 & 4.46 & 4.99 & 5.68 & 6.43 & 6.79 & 7.17 & 7.30 & 7.53 \\
\hline & West & 3.63 & 3.96 & 4.09 & 4.44 & 4.94 & 5.61 & 6.23 & 6.55 & 6.94 & 6.51 & 6.62 \\
\hline
\end{tabular}

Sources: Authors and Fan et al. (2011) for marketization index. 
Table 4. Separate effects of ownership and institutions on labor productivity

\begin{tabular}{|c|c|c|c|c|}
\hline FE model & (1) & (2) & (3) & (4) \\
\hline \multirow[t]{2}{*}{ In(capital to labor ratio) } & 0.168 & 0.168 & 0.167 & 0.166 \\
\hline & $(0.00)^{\star \star *}$ & $(0.00)^{\star \star \star}$ & $(0.00)^{\star \star \star}$ & $(0.00)^{\star * *}$ \\
\hline \multirow[t]{2}{*}{ In(employ) } & -0.360 & -0.362 & -0.362 & -0.363 \\
\hline & $(0.00)^{\star * *}$ & $(0.00)^{* \star *}$ & $(0.00)^{\star \star \star}$ & $(0.00)^{\star \star *}$ \\
\hline \multirow[t]{2}{*}{$\ln ($ age $)$} & 0.050 & 0.051 & 0.051 & 0.052 \\
\hline & $(0.00)^{\star * *}$ & $(0.00)^{\star * *}$ & $(0.00)^{\star * *}$ & $(0.00)^{\star * *}$ \\
\hline \multirow[t]{2}{*}{$\ln (\text { debt ratio })_{t-1}$} & 0.028 & 0.029 & 0.030 & 0.030 \\
\hline & $(0.00)^{\star * *}$ & $(0.00)^{\star * *}$ & $(0.00)^{\star * *}$ & $(0.00)^{\star * *}$ \\
\hline \multirow{2}{*}{$\ln (\text { current ratio })_{\mathrm{t}-1}$} & 0.022 & 0.023 & 0.023 & 0.023 \\
\hline & $(0.00)^{\star \star \star}$ & $(0.00)^{\star \star \star}$ & $(0.00)^{\star \star *}$ & $(0.00)^{\star \star \star}$ \\
\hline \multirow[t]{2}{*}{ state } & & -0.082 & & -0.079 \\
\hline & & $(0.01)^{* \star *}$ & & $(0.01)^{\star * *}$ \\
\hline \multirow[t]{2}{*}{ foreign } & & 0.123 & & 0.122 \\
\hline & & $(0.01)^{\star * \star}$ & & $(0.01)^{\star \star *}$ \\
\hline \multirow[t]{2}{*}{ In(college graduates) } & & & 0.152 & 0.151 \\
\hline & & & $(0.01)^{\star \star *}$ & $(0.01)^{\star * \star}$ \\
\hline \multirow[t]{2}{*}{ In(inventions) } & & & 0.008 & 0.009 \\
\hline & & & $(0.01)$ & $(0.01)$ \\
\hline \multirow{2}{*}{$\begin{array}{l}\text { In(length of } \\
\text { railway+highway) }\end{array}$} & & & 0.148 & 0.148 \\
\hline & & & $(0.01)^{\star \star \star}$ & $(0.01)^{\star * *}$ \\
\hline \multirow[t]{2}{*}{ In(marketization index) } & & & 0.114 & 0.111 \\
\hline & & & $(0.02)^{\star \star *}$ & $(0.02)^{\star \star \star}$ \\
\hline \multirow[t]{2}{*}{ constant } & 6.325 & 6.336 & 5.636 & 5.657 \\
\hline & $(0.05)^{\star \star \star}$ & $(0.05)^{\star \star \star}$ & $(0.08)^{\star \star *}$ & $(0.08)^{\star * \star}$ \\
\hline R-Square & 0.253 & 0.253 & 0.255 & 0.255 \\
\hline N & 870,138 & 870,138 & 870,089 & 870,089 \\
\hline Hausman Test & $36,396.82^{\star \star *}$ & $34702.91^{* * *}$ & $37358.87^{\star * *}$ & $35049.08^{* * *}$ \\
\hline
\end{tabular}

Notes: 1 . Numbers in parentheses are standard errors. $2 .{ }^{* * *},{ }^{* *}$, and ${ }^{*}$ in the cells indicate $1 \%, 5 \%$, and $10 \%$ levels of significance, respectively. 3. Year, industry, and province dummies are included, but the results are not reported.

2. In the fixed effect estimation, time-invariant dummy variables are dropped because of perfect collinearity with the firm fixed effects. However, a few companies in our sample changed their location (province) or industry; hence the dummies were retained in such cases. Sources: Authors. 
Table 5. Interaction effects of ownership and institutions

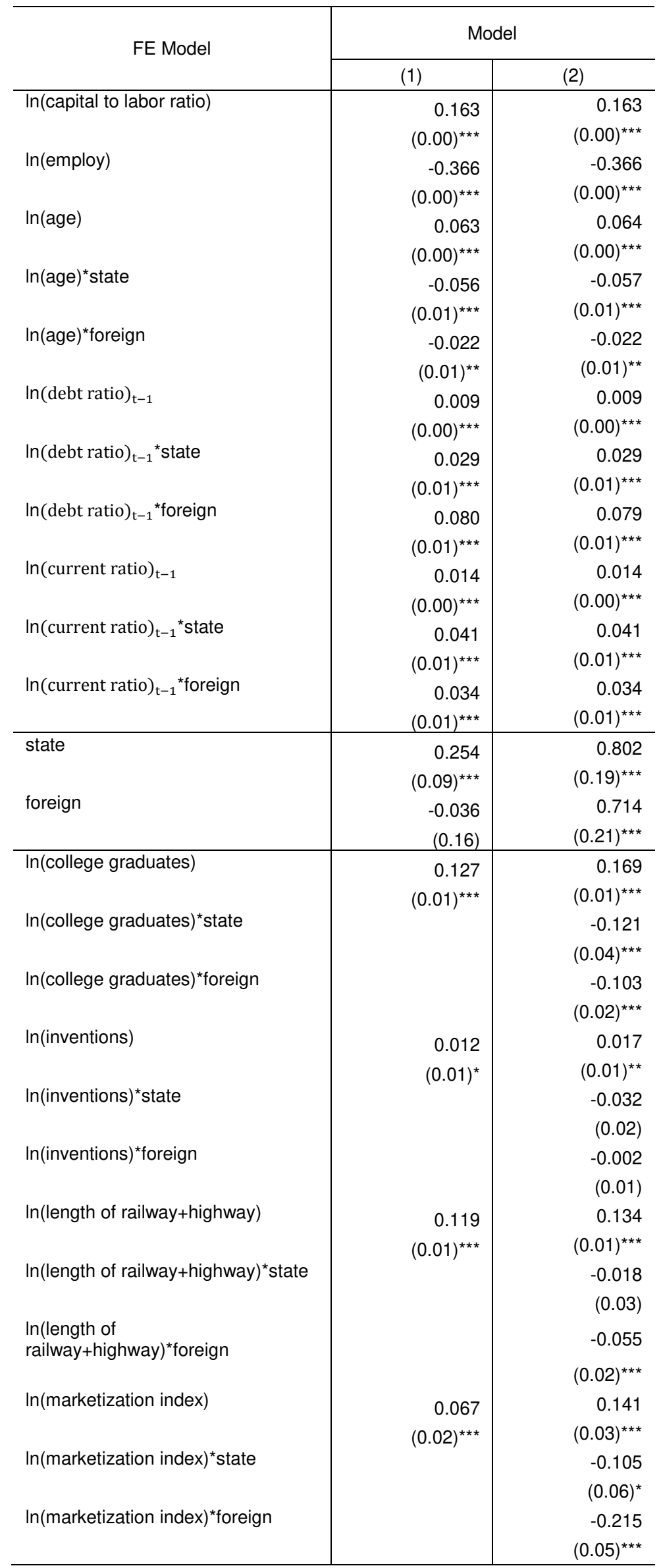




\begin{tabular}{l|r|r}
\hline constant & 5.836 & 5.560 \\
& $(0.08)^{\star \star \star}$ & $(0.09)^{\star \star \star}$ \\
\hline R-square & 0.259 & 0.260 \\
$\mathrm{~N}$ & 870,089 & 870,089 \\
Hausman Test & $36284.61^{\star * \star}$ & $37424.81^{\star \star *}$ \\
\hline
\end{tabular}

Notes: 1 . Numbers in parentheses are standard errors. $2 .{ }^{* * *},{ }^{* *}$, and ${ }^{*}$ in the cells indicate $1 \%, 5 \%$, and $10 \%$ levels of significance, respectively. 3. Year, industry, and province dummies are included, but the results are not reported Sources: Authors. 
Table 6. Summary of the Effects of Institutional Development on Labor Productivity by Ownership

\begin{tabular}{lrrr}
\hline & Private & \multicolumn{1}{c}{ State } & \multicolumn{1}{c}{ Foreign } \\
\hline In(college graduates) & 0.169 & 0.048 & 0.066 \\
& $(0.01)^{\star * *}$ & $(0.23)$ & $(0.15)^{\star * \star}$ \\
In(inventions) & 0.017 & -0.015 & 0.015 \\
& $(0.01)^{* *}$ & $(0.01)$ & $(0.00)^{\star}$ \\
In(length of & 0.134 & 0.116 & 0.079 \\
railway+highway) & $(0.01)^{\star * *}$ & $(0.19)^{\star * *}$ & $(0.13)^{\star * \star}$ \\
In(marketization index) & 0.141 & 0.036 & -0.074 \\
& $(0.03)^{\star * *}$ & $(0.03)$ & $(0.35)^{\star *}$ \\
\hline
\end{tabular}

Notes: 1 . Numbers in parentheses are standard errors. $2 .{ }^{* * *},{ }^{* *}$, and ${ }^{*}$ in the cells indicate $1 \%, 5 \%$, and $10 \%$ levels of significance, respectively. 3 . See the text on how we obtained these figures.

Sources: Authors.

Table 7. Robustness Test 1: Effects of Institutional Development on Labor Productivity by Ownership

\begin{tabular}{|c|c|c|c|c|c|c|}
\hline & \multicolumn{2}{|c|}{ Private } & \multicolumn{2}{|c|}{ State } & \multicolumn{2}{|c|}{ Foreign } \\
\hline & (1) & (2) & (3) & (4) & (5) & (6) \\
\hline \multirow[t]{2}{*}{ In(capital to labor ratio) } & 0.151 & 0.150 & 0.191 & 0.191 & 0.166 & 0.165 \\
\hline & $(0.00)^{\star * *}$ & $(0.00)^{\star * *}$ & $(0.01)^{\star * *}$ & $(0.01)^{\star * *}$ & $(0.00)^{\star * \star}$ & $(0.00)^{\star * *}$ \\
\hline \multirow[t]{2}{*}{ In(employ) } & -0.404 & -0.406 & -0.299 & -0.301 & -0.347 & -0.348 \\
\hline & $(0.00)^{\star * *}$ & $(0.00)^{\star \star \star}$ & $(0.02)^{\star \star \star}$ & $(0.02)^{\star \star \star}$ & $(0.01)^{\star \star \star}$ & $(0.01)^{\star \star \star}$ \\
\hline \multirow[t]{2}{*}{$\ln ($ age $)$} & 0.061 & 0.062 & 0.019 & 0.020 & 0.063 & 0.062 \\
\hline & $(0.00)^{\star \star *}$ & $(0.00)^{\star \star \star}$ & $(0.01)$ & $(0.01)$ & $(0.01)^{\star \star \star}$ & $(0.01)^{\star \star \star}$ \\
\hline \multirow[t]{2}{*}{$\ln (\text { debt ratio })_{t-1}$} & 0.004 & 0.006 & 0.038 & 0.037 & 0.087 & 0.087 \\
\hline & $(0.00)$ & $(0.00)^{*}$ & $(0.01)^{\star \star \star}$ & $(0.01)^{\star \star *}$ & $(0.01)^{\star \star *}$ & $(0.01)^{\star \star \star}$ \\
\hline \multirow[t]{2}{*}{ In (current ratio) $)_{t-1}$} & 0.012 & 0.012 & 0.059 & 0.059 & 0.048 & 0.048 \\
\hline & $(0.00)^{\star * *}$ & $(0.00)^{\star \star \star}$ & $(0.01)^{\star * \star}$ & $(0.01)^{\star \star *}$ & $(0.00)^{\star * *}$ & $(0.00)^{\star \star \star}$ \\
\hline \multirow[t]{2}{*}{ In(college graduates) } & & 0.176 & & 0.025 & & 0.062 \\
\hline & & $(0.01)^{\star \star *}$ & & $(0.04)$ & & $(0.02)^{\star \star \star}$ \\
\hline \multirow{2}{*}{ In(inventions) } & & 0.019 & & -0.012 & & 0.013 \\
\hline & & $(0.01)^{\star \star}$ & & $(0.02)$ & & $(0.01)$ \\
\hline \multirow[t]{2}{*}{ In(length of railway+highway) } & & 0.131 & & 0.124 & & 0.067 \\
\hline & & $(0.01)^{\star \star \star}$ & & $(0.03)^{\star \star \star}$ & & $(0.02)^{\star \star \star}$ \\
\hline \multirow[t]{2}{*}{ In(marketization index) } & & 0.125 & & 0.025 & & -0.092 \\
\hline & & $(0.03)^{\star * *}$ & & $(0.05)$ & & $(0.04)^{\star *}$ \\
\hline \multirow[t]{2}{*}{ constant } & 6.629 & 5.852 & 5.523 & 5.374 & 6.492 & 6.505 \\
\hline & $(0.06)^{\star * *}$ & $(0.10)^{\star * *}$ & $(0.23)^{\star * *}$ & $(0.28)^{\star * *}$ & $(0.19)^{\star * *}$ & $(0.22)^{\star \star *}$ \\
\hline R-square & 0.289 & 0.291 & 0.166 & 0.167 & 0.226 & 0.227 \\
\hline $\mathrm{N}$ & 602585 & 602569 & 83730 & 83700 & 183823 & 183820 \\
\hline Hausman Test & $14136.04^{\star \star *}$ & $14381.45^{\star * *}$ & $5195.42^{* * *}$ & $5214.89^{* * *}$ & $7864.26^{* * *}$ & $7911.96^{\star \star \star}$ \\
\hline
\end{tabular}

Notes: 1 . Numbers in parentheses are standard errors. $2 .{ }^{* * *}, * *$, and ${ }^{*}$ in the cells indicate $1 \%, 5 \%$, and $10 \%$ levels of significance, respectively. 3. Year, industry, and province dummies are included, but the results are not reported Sources: Authors.

Table 8. : Labor Productivity by Ownership Type (Value Added Per Worker) 


\begin{tabular}{|c|c|c|c|c|c|c|c|c|c|c|}
\hline $\begin{array}{c}\text { Ownershi } \\
\mathrm{p}\end{array}$ & 1998 & 1999 & 2000 & 2001 & 2002 & 2003 & 2004 & 2005 & 2006 & 2007 \\
\hline Full & 51.1 & 47.9 & n.a. & 56.7 & 63.9 & 75.1 & n.a. & 97.7 & 115.3 & 130.5 \\
\hline State & 27.5 & 26.9 & n.a. & 32.1 & 35.8 & 47.3 & n.a. & 69.5 & 85.2 & 121.7 \\
\hline Private & 54.3 & 50.6 & n.a. & 56.2 & 63.4 & 72.1 & n.a. & 95.5 & 113.2 & 128.6 \\
\hline Foreign & 87.6 & 75.2 & n.a. & 84.1 & 89.0 & 101.8 & n.a. & 113.8 & 130.8 & 139.6 \\
\hline
\end{tabular}

Note. All values are denoted in 1,000 Chinese Yuan (1,000 RMB)

Sources: Authors.

Table 9. Robustness Test 2: Effects of Institutional Development on Labor Productivity by Ownership

\begin{tabular}{|c|c|c|c|c|c|c|}
\hline & \multicolumn{2}{|c|}{ Private } & \multicolumn{2}{|c|}{ State } & \multicolumn{2}{|c|}{ Foreign } \\
\hline & (1) & (2) & (3) & (4) & (5) & (6) \\
\hline \multirow[t]{2}{*}{ In(capital to labor ratio) } & 0.141 & 0.140 & 0.151 & 0.151 & 0.157 & 0.157 \\
\hline & $(0.00)^{\star \star \star}$ & $(0.00)^{\star \star \star}$ & $(0.02)^{\star \star \star}$ & $(0.02)^{\star \star *}$ & $(0.01)^{\star \star *}$ & $(0.01)^{\star \star \star}$ \\
\hline \multirow[t]{2}{*}{ In(employ) } & -0.456 & -0.457 & -0.431 & -0.433 & -0.371 & -0.371 \\
\hline & $(0.01)^{\star \star \star}$ & $(0.01)^{\star \star \star}$ & $(0.03)^{\star \star \star}$ & $(0.03)^{\star * *}$ & $(0.01)^{\star \star *}$ & $(0.01)^{\star \star *}$ \\
\hline \multirow[t]{2}{*}{$\ln ($ age $)$} & 0.014 & 0.015 & 0.019 & 0.02 & 0.151 & 0.151 \\
\hline & $(0.01)^{\star}$ & $(0.01)^{\star \star}$ & $(0.02)$ & $(0.02)$ & $(0.02)^{\star \star *}$ & $(0.02)^{\star \star *}$ \\
\hline \multirow[t]{2}{*}{$\ln (\text { debt ratio })_{t-1}$} & -0.007 & -0.006 & 0.017 & 0.018 & 0.052 & 0.052 \\
\hline & $(0.00)$ & $(0.00)$ & $(0.01)$ & $(0.01)$ & $(0.01)^{\star \star *}$ & $(0.01)^{\star \star \star}$ \\
\hline \multirow[t]{2}{*}{$\ln (\text { current ratio })_{t-1}$} & 0.001 & 0.001 & 0.044 & 0.044 & 0.035 & 0.035 \\
\hline & $(0.00)$ & $(0.00)$ & $(0.01)^{\star \star \star}$ & $(0.01)^{\star \star \star}$ & $(0.01)^{\star \star *}$ & $(0.01)^{\star \star \star}$ \\
\hline \multirow[t]{2}{*}{ In(college graduates) } & & 0.145 & & 0.092 & & 0.056 \\
\hline & & $(0.02)^{\star \star \star}$ & & $(0.06)$ & & $(0.03)^{*}$ \\
\hline \multirow[t]{2}{*}{ In(inventions) ${ }^{11}$} & & 0.008 & & 0.039 & & -0.009 \\
\hline & & $(0.01)$ & & $(0.03)$ & & $(0.02)$ \\
\hline \multirow[t]{2}{*}{ In(length of railway+highway) } & & 0.09 & & 0.069 & & -0.001 \\
\hline & & $(0.01)^{\star \star \star}$ & & $(0.04)^{*}$ & & $(0.03)$ \\
\hline \multirow[t]{2}{*}{ In(marketization index) } & & 0.216 & & -0.076 & & 0.065 \\
\hline & & $(0.04)^{\star \star \star}$ & & $(0.07)$ & & $(0.07)$ \\
\hline \multirow[t]{2}{*}{ constant } & 5.834 & 4.938 & 4.867 & 4.807 & 5.183 & 4.873 \\
\hline & $(0.04)^{\star \star \star}$ & $(0.12)^{\star \star \star}$ & $(0.20)^{\star \star \star}$ & $(0.30)^{\star \star *}$ & $(0.09)^{\star \star *}$ & $(0.22)^{\star * *}$ \\
\hline \multirow{2}{*}{$\begin{array}{l}\text { R-square } \\
\mathrm{N}\end{array}$} & 0.180 & 0.181 & 0.127 & 0.127 & 0.107 & 0.108 \\
\hline & 377,652 & 377,636 & 66,459 & 66,429 & 118,264 & 118,261 \\
\hline \multicolumn{7}{|c|}{$\begin{array}{l}\text { Notes: } 1 \text { Numbers in parentheses are standard errors. } 2 .{ }^{* * *},{ }^{* *}, \text { and }{ }^{*} \text { in the cells indicate } 1 \%, 5 \% \text {, and } 10 \% \\
\text { levels of significance, respectively. 3. Year, industry, and province dummies are included, but the results are } \\
\text { not reported }\end{array}$} \\
\hline
\end{tabular}

\footnotetext{
11 The result that affirms that knowledge capital is insignificant is consistent with the interpretation of Table 4 (page 15), which suggests that the rampant copyright infringement in China is caused by weak copyright protection.
} 
Figure 1. Dynamics of the relationship between institutional development and productivity according to firm ownership

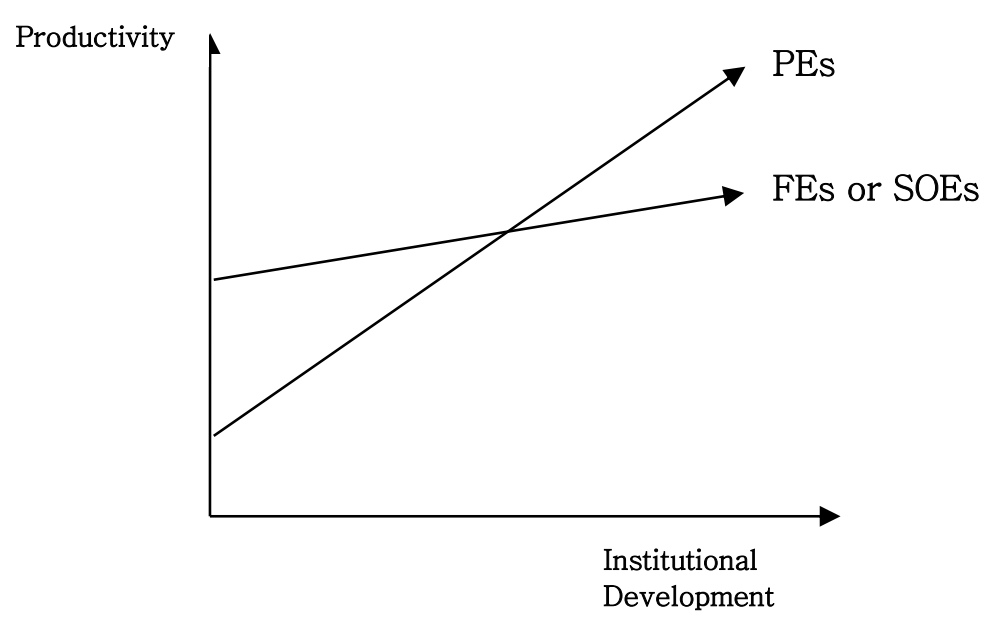

